\title{
Elite Power Under Advanced Neoliberalism
}

\author{
William Davies
}

This is a pre-print of an article forthcoming in Theory Culture \& Society 


\title{
Elite Power Under Advanced Neoliberalism
}

William Davies

\begin{abstract}
The financial crisis, and associated scandals, created a sense of a juridical deficit with regard to the financial sector. Forms of independent judgement within the sector appeared compromised, while judgement over the sector seemed unattainable. Elites, in the classical Millsian sense of those taking tacitly coordinated, 'big decisions' over the rest of the public, seem absent. This article argues that the eradication of jurisdictional elites is an effect of neoliberalism, as articulated most coherently by Hayek. It characterises the neoliberal project as an effort to elevate 'unconscious' processes over 'conscious' ones, which in practice means elevating cybernetic, non-human systems and processes over discursive spheres of politics and judgement. Yet such a system still produces its own types of elite power, which come to consist in acts of translation, rather than judgment. Firstly, there are 'cyborg intermediaries': elites which operate largely within the system of codes, data, screens and prices. Secondly, there are 'diplomatic intermediaries': elites who come to narrate and justify what markets (and associated technologies and bodies) are 'saying'. The paper draws on Lazzarato's work on signifiying vs asignifying semiotics in order to articulate this, and concludes by considering the types of elite crisis which these forms of power tend to produce.
\end{abstract}

Keywords: elites, neoliberalism, finance, Hayek, capitalism, Lazzarato

Word Length: 9794 
In the aftermath of the banking crises of 2007-09, and amidst subsequent scandals such as Libor-fixing, there was a palpable public sentiment that judgement was not being adequately cast over financial elites. While a handful of proven criminals were jailed in the US, UK and elsewhere, the sense that bankers had 'got away with it' was widespread. Fines placed on Wall Street banks between 2009-14 only amounted to $26 \%$ of the profits made over the same period, while just one Wall Street executive was jailed (Cohan, 2015; Spross, 2015). To fill the vacuum of normative regulation, recriminations took on an air of pre-modernity. In 2012, Fred Goodwin, the former CEO of UK bank RBS, was stripped of the Knighthood he had been awarded in 2004 for "services to banking". A 'bankers oath' was introduced in Holland in 2013, concluding with the words "so help me God". Warren Buffett argued that only the threat of incarceration was sufficient to alter the behavior of Wall Street bankers. Others have suggested that banks be stripped of the protection of limited liability, which would shrink banking to a mid-Victorian scale of risk-taking, and place potentially ruinous levels of liability upon bankers as well as shareholders (Haldane, 2011).

In addition to the deficiency of legal judgement, there was a sense that the systems of judgement and accountability used within the financial system had become subverted by monetary incentives and cultural intimacy. The capacity for disinterested judgement had been destroyed. Credit-rating agencies and Big Four accounting firms, whose judgments of risk and propriety are critical for the public accountability of financial and non-financial firms, were revealed by investigative journalists as working to manipulate profit and risk calculations on behalf of clients (Lewis, 2011; Shaxson, 2011; ICIJ, 2014). The UK's Competition Commission reported that the Big Four were not fulfilling their duty as auditors, due to excessive proximity to the managers of firms they audit (Competition Commission, 2013).

These various scandals and crises suggest a widespread collapse of juridical reason as a symptom and malaise of financialisation. Financial institutions and agencies appear to undermine the capacity for independent, objective judgement over the 'facts' of what is taking place, while the complexity of institutions and instruments is such that very few external public or juridical actors are able to form judgments from positions of liberal disinterestedness. The offshoring of financial capital to escape 
taxation and regulation is now well-recognised, but it is also enabling a new class of extra-juridical elites, who are able to operate outside of ordinary legal norms of citizenship, such as the requirement to show a passport when crossing borders (Harrington, 2015). And even after a crisis that cost some national economies a sum comparable to that of a world war (Haldane, 2012b), the search for judgement and justice seemed equally frustrated, hence appeals to pre-modern policies such as oaths.

These events put strain on the conventional concept of 'elites', as proposed in the classical formulations of Mills and Dahl, and which some scholars have sought to revive in the context of rising inequality and financialisation (Mills, 1999; Dahl, 1958; Savage \& Williams, 2008a; Kahn, 2012). For while it is now abundantly clear that a small minority of executives and financial intermediaries are benefiting hugely from finance-led capitalism (Piketty, 2014; Dorling, 2014), those individuals and agencies lack the public, cultural or political status that elites have traditionally been accredited with, for better or worse. One of the sociological challenges of contemporary inequality is how to treat concentrations of wealth as a private, domestic, monetary and economic phenomenon, and not assume that this is translated into (or derived from) political power, public status or cultural capital, as Weberian and Bourdieusian traditions have done (Savage, 2014a, 2014b). The financial elite today is arguably characterised by an absence of public identity, and an absence of juridical reason, whereas the classical theory of elites places them in relation to a liberal public sphere, even if they lack a Kantian spirit of disinterestedness in their engagement with it. The Millsian problem of elites is one of rival political jurisdictions - over corporations, state, military - just as professions are conceived as rival epistemological jurisdictions (Abbott, 1988), which combine to form a jurisdiction over the public at large. But financial elites neither exercise nor recognise juridical reason, in the sense of exercise of public judgement.

One way in which this new elite formation has been theorised is via the concept of the "capillary power" of finance (Savage \& Williams, 2008b). Savage and Williams suggest that the Millsian theory of elites needs updating, both in light of poststructuralist critiques of agency, and in view of the rise of decentralised, highly mediated, technical networks in the financial economy. As they argue, "the challenge in present day capitalism is to understand the disorganizing power of finance materialized in a loose distributive coalition of intermediaries whose power works unpredictably through temptation" (Savage \& Williams, 2008b: 12). As per 
Foucauldian and Latourian accounts of power, contemporary elites are no longer centralised in hierarchical institutions of the sort that concerned Mills. The power of financial intermediaries lies partly in their capacity to act without the trappings of authority or public status.

This article does not contradict that diagnosis of the problem, but seeks to build on it by considering contemporary elite power as 'post-juridical', in the sense that it exists outside of any norms of discourse or conducts. This is not true of all forms of "capillary power". Foucauldian 'discipline' is resolutely normative, indeed normalising, in its methods and effects. Institutions of 'discipline' are decentralised and micropolitical; but they share certain normative patterns with more public or macroinstitutions, such as professional associations, market regulation, bureaucracies and so on. These technologies are tangible effects of discourses which are prior to them. A major challenge of liberal government, from a Foucauldian perspective, is precisely how to convert macro-political goals into micro-political techniques and interventions (Rose \& Miller, 2010). 'Disciplinary power' is therefore compatible with the notion of 'hegemony', for both imply an a priori principle which is to be applied in general (Lash, 2007). The challenge posed by contemporary financial elites is not only that their power is "capillary" in nature, but that it is not authorised by any public, normative or juridical regime which exists prior to the power itself, making it "posthegemonic" or "exceptional" in nature (Davies, 2013, 2016). The power of finance is less that of normative 'discipline', and more that of constantly reactive 'control' (Deleuze, 1992). The desperation for a juridical principle to be reasserted over finance reflects a nostalgic longing for a priori reason, even if it has a somewhat mediaeval hue.

Conceived in a post-juridical sense, elites are neither inside nor outside of the law, neither applying rules nor breaking them. So how might we understand them, in a political and pragmatist sense? The argument to be developed here is that their power consists in the power of translation, and that this is in keeping with a longstanding neoliberal critique of professional, political and epistemological authority. When liberal disciplines, methodologies, laws and regulations are abandoned in favour of cybernetic systems of digits, machines and prices (including those of markets), what remains is a type of elite power which interprets what is on the screen, explains what it means, converts it into narrative, but possesses no authorship or authority over it. The elite becomes the go-between, communicating what 'the markets' (or other machines) are saying, for a liberal, public audience which 
is otherwise excluded from such knowledge. This elite power was noticed in the early 1990s by sociologists seeking to understand why globalisation appeared to still privilege certain cultures and territories, often being described as an embedded class of "symbolic analysts" (Sassen, 1991; Reich, 2010; Castells, 1996). But beyond its economic geography, the cultural, technological and political dimensions of this elite were less studied. This elite inhabits and interprets an encoded semiotic system which derives from machines, rather than from political or juridical discourse. Lazzarato's rich analysis of 'machinic enslavement' and 'asignifying semiotics' offers a useful theoretical starting point for critical reflection on this, as I shall explore (Lazzarato, 2014).

To interpret this post-juridical variety of elite power, I will highlight certain resonances and differences between the classical Millsian critique of elites and the definitively neoliberal critique of 'intellectuals' and 'planners' developed by Friedrich Hayek and some of his associates. Where Mills was concerned that elites had become too concentrated and too distant from the demos, Hayek's specific anxiety was that elites had conscious objectives for society in mind. Neoliberalism, interpreted via Hayek, can therefore be understood as an attempt to imagine and design a new form of elite power, which lacks the aspiration to act on behalf of the public. The absence of juridical reason in our financial system today may be understood as the logical outcome of this model of critique which elevates unconscious decisions over conscious ones. In a world transformed by neoliberal reason, the Millsian critique loses some purchase, because elites are no longer configured along the lines of Weberian law-enforcers. The question is how to define them otherwise, to which I offer an ideal type of the power of translation.

The rest of the article is in four sections. Firstly, I return to the classical theory of elites as presented by Mills, highlighting its Weberian assumptions and juridical - that is, procedurally rational - view of power. Whether viewed critically (as Mills did) or enthusiastically (either for conservative or pluralist reasons), elites of this nature held public status, forms of authority, and public oversight. The original question of elite studies was a liberal one: do elite jurisdictions overlap and conspire, rendering them illegitimate, or hold each other in check as pluralists argue they should? Secondly, I discuss the critique of this vision of power that was mounted by Hayek and other neoliberal thinkers. The critique of 'conscious' planning, modern rationalism, intellectual discipline was also a critique of panoptical and juridical power. Against Cartesian epistemologies, neoliberals asserted the primacy of embodied, instinctive 
actors (entrepreneurs and consumers) governed by non-representative, cybernetic systems, of which the price system was the pre-eminent example. Thirdly, I explore what form of elite power is implicit within this neoliberal critique, which is the power to report what numbers and embodied movements mean, or else to remain entirely immersed in computational systems without any public status or authority. To explore this, I draw on Lazzarato's distinction between 'subjection' and 'machinic enslavement', where the former acts via discourse upon conscious cognition, and the latter acts via non-discursive semiotics, via unconscious, bodily and technological mechanisms (Lazzarato, 2014). The paper concludes by indicating some contemporary crises of this elite.

The empirics of elite studies are always a thorny problem (Nader, 1972). In many ways, this is the terrain of investigative journalists and deeply embedded anthropologists, both of which have proved valuable sources in understanding contemporary finance. There is arguably always something scandalous about the concept of 'elites', as the very notion can imply a shortage of legitimacy or transparency, which in turn raises methodological and epistemological questions for elite sociology. This paper does not contain new empirical evidence on the existence or otherwise of an integrated 'power elite', but it does offer an interpretation of how the problem of elite power (including its legitimacy crisis) now presents itself. It develops this narrative largely on the back of published news stories and investigations which have managed to puncture otherwise opaque elite cultures. The epistemological quality of such material is ambiguous by nature, seeing as it is often in the form of an exposé. Sociological interpretation can nevertheless respond to the way in which such revelations and scandals now present themselves. There is, I will suggest, a qualitatively different aspect to elite power today (compared to Mills' day) which becomes apparent as we read between reportage and social theory. This is the approach taken here.

\section{Elite jurisdictions}


In his classic work, The Power Elite, Mills defines the power elite as "those political, economic, and military circles which as an intricate set of overlapping cliques share decisions having at least national consequences. In so far as national events are decided, the power elite are those who decide them" (Mills, 1999: 18). The institutions which the elite control, namely the state, corporations and the military, occupy different spheres of society, with different domains of jurisdiction. However, a central contention of Mills' work is that these separate institutions share a common characteristic, namely the extreme gradation of power separating the top from the bottom. Hence, those who operate at the highest level of state, corporations and military have more in common with each other than they do with ordinary members of the public or indeed with those who work in those institutions at more junior levels.

Mills' critique of the power elite is simultaneously democratic and liberal in nature. It is democratic in the sense that the power differential between the elite and the public now excludes the latter from influence over decision-making. People "feel that they live in a time of big decisions; they know that they are not making any" (Mills, 1999: 5). By this critical standard, the threat posed by the power elite is that they are too far removed from ordinary people, and effectively operating outside of or above the public sphere. They issue commands, which those outside of the elite are required to obey, by virtue of the particular means at the elite's disposal. Modernity witnesses an expansion in elite jurisdictions, as technology becomes more sophisticated and power networks become national in reach. Hence "it is the form and the height of the gradation of power that we must examine if we would understand the degree of power held and exercised by the elite" (1999: 18). By virtue of hierarchical scale and technological reach, the elite attain a form of positive political liberty - freedom to which is not available to anybody else. In that sense, elites are an anti-democratic force. They are hoarders of power that would otherwise lie with the populace.

While the populist tone of Mills' critique may be more emotive, it is the liberal argument that has been more significant for the direction of elite studies. Central to Mills' critique of elites is the idea that they have become not only separate from the demos but also integrated with each other. By virtue of their extreme seniority and power, they develop a shared psychology and culture, which makes their positions virtually interchangeable, despite the differences between the institutions below them (1999: 19). Most crucially, they are able to coordinate their actions so as to pursue deliberate political agendas together: "as the institutional mechanics of our time have opened up avenues to men pursuing their several interests, many of them have 
come to see that these several interests could be realized more easily if they worked together" (1999: 20). Chief Executives are able to leave the running of businesses to the managers and bureaucrats below them, and focus their efforts on ingratiating themselves with politicians. Political, military and economic objectives can be pursued in tandem, as the idea of the 'military industrial complex' later pointed towards, once the power elite are working as an interconnected political entity.

By arguing that the power elite is a single entity, albeit operating with different formal jurisdictions, Mills challenged the pluralist theory of elite power that has come to be associated with Dahl (Dahl, 2005), but which can also be traced to Weber and Schumpeter (Weber, 1991; Schumpeter, 1976). In the face of the same forces of modernity which Mills believed had generated a power elite, liberal pluralism states that participatory democracy is no longer a realistic possibility, but that a version of the liberal separation of powers is. With respect to democracy, Schumpeter outlined a theory of "competitive leadership", in which the majority were excluded from political decision-making, but were protected from tyranny by the conflicts between political parties, just as corporations and entrepreneurs would constantly challenge each other (1976: 269-273). Dahl famously argued against Mills that the alleged concentration of power in a single elite was impossible to verify empirically (Dahl, 1958), and that US society instead retained a plurality of disconnected, mutually antagonistic centres of power (Dahl, 1982, 2005). The problem with elites, according to this view, is not the 'height' to which they have risen, but whether or not they operate in a coordinated fashion; Dahl believed there was no evidence that they did. More recently, Mizruchi has returned to this same dispute, but to argue that elite legitimacy is weakened precisely because elites have become decentralised and 'fractured' (Mizruchi, 2013). This leaves them unable to take the sort of deliberate, coordinated approach to collective problems that Mills criticised, but which might now actually be welcome.

Putting the empirical question of elite coordination to one side, we can see that the problematic of elites is one of jurisdictions, that is, of the legitimate scope of monopoly power. Underlying these rival positions is a Weberian question of the limits to instrumental rationality and technology, and a normative assumption that legitimacy is attained through a plurality of value spheres, even while each one may involve high levels of political centralisation. To employ Walzer's distinction, elites might (from a liberal perspective) legitimately maintain 'monopolies' over specific instruments or spheres of power, so long as they don't acquire 'domination' over rival 
ones (Walzer, 1984). This is precisely how the legitimacy of professional power can be understood: exclusive jurisdictions run up against other exclusive jurisdictions (Abbott, 1988). A profession that claimed jurisdiction over everything would no longer be a profession, but a form of epistemological tyranny. But the critique of elite power - or professional power - is that the plurality of jurisdictions conceals a more fundamental inequality.

In keeping with the Weberian premises, elites of this nature are reflexive actors, whose actions carry meaning for themselves and are governed by their own normative presuppositions or 'vocations'. Their agency is partly constituted by how they subjectively interpret what they are doing, that is, they know what they are doing, even if they can't fully articulate the norms governing how they do it. The exercise of elite power is conscious and 'willful', with an active subject as its driving force. As Savage and Williams note, the elite studies of the 1950s and '60s were marked by a 'humanistic' bent, that privileged the power of knowing subjects (in a sometimes journalistic way), and provoked the structuralist and post-structuralist critiques over subsequent decades which rendered elite studies somewhat outmoded (Savage \& Williams, 2008). The locus of power shifted from reflexive agents, towards discourses, technologies, knowledges, diagrams, where it was performed in everyday life, often invisibly.

But before structuralist and post-structuralist critiques had emerged, there was another tradition of constructivist, epistemological critique which may not have carried much significance for the fate of elite studies, but has arguably done much to transform elite power itself: neoliberalism. Emerging simultaneously with pragmatist, democratic critiques of expertise (which had influenced Mills), the neoliberal critique belonging to Hayek in particular offers another distinctive analysis of elite power which is more specifically epistemological in nature, and focuses on the dangers of 'scientism' and 'conscious' public decision-making. We need to consider the neoliberal critique of elite power, partly so as to understand what variety of elite power is then possible under neoliberalism. On the basis that economic institutions, regulations and practices are shaped by certain 'critical capacities' (Boltanski \& Thevenot, 1999), the neoliberal critique of elite power-knowledge is arguably of performative and political significance, and can help us understand what constitutes elites under neoliberalism. I want to suggest that it is the juridical nature of elite power that neoliberal critique targets, and which opens up possibilities for postjuridical elites that are features of financialisation. Crucially, neoliberal critique targets 
those with a reflexive, conscious sense of themselves as elites, with responsibility for public decision-making. But this leaves open the possibility of a different variety of elite, who lack this juridical or quasi-juridical orientation.

\section{The neoliberal critique of elites}

From the beginning of the socialist calculation debate in 1920, the primary target of neoliberal critique is the economic planner, who intends to deliver certain economic outcomes by force of political will and governmental rationality (Mises, 1990, 2009; Hayek, 1944). As a body of thought, neoliberalism can therefore be understood initially as a critique of economic planning, which aims to open up space for competitive market mechanisms, while retaining necessary elements of the Keynesian or socialist political economic framework (Burgin, 2012). The targets of this critique exist across the political spectrum, including both socialism and fascism, which are perceived as united in their hostility to unplanned, competitive dynamics (Hayek, 1944: 42).

Like Mills' power elite, the planner is deemed guilty of operating outside of the conditions of everyday life, imposing his will upon the mass from a position of exteriority. Mills' complaint that people "feel that they live in a time of big decisions; they know that they are not making any" could equally have been made by Hayek. And like Mills, one of Hayek's concerns was that planners act 'consciously' and 'deliberately', and seek to repress emergent social forces which arise spontaneously. Hayek argued of economic planning:

We have in effect undertaken to dispense with the forces which produced unforeseen results and to replace the impersonal and anonymous mechanism of the market by collective and "conscious" direction of all social forces to deliberately chosen goals.

(Hayek, 1944: 21)

The liberalism - or neoliberalism - which Hayek and his associates in the Mont Pelerin Society (founded 1947) hoped to design would involve inverting this relationship, such that unplanned forces of competition would replace the power of 'conscious' and 'deliberate' pursuit of collective ends. One might even frame this in Mills' own language, and suggest that in the ideal neoliberal society, people would 
know that they did not live in a time of big decisions, but feel that they are making some. There are therefore some obvious resonances between a democratic New Left critique of elite power and a neoliberal critique of elite power, which became instrumental to how applied neoliberalism channelled ideals of self-expression and democracy into work (Boltanski \& Chiapello, 2007), financial markets (Frank, 2010) or the freedom of capital more generally (Harvey, 2005).

What distinguishes the neoliberal critique from the democratic or liberal critique is its attention to the epistemological limitations of centralised expertise. Mills was concerned by the lack of knowledge of the power elite, their instrumentalism and reliance on 'experts'. But this was as much a normative judgement of their intellectual mediocrity and 'mindless' lack of concern with teleological, substantive political discussion (1999: 350-356). They dominated public life, despite having no vocation towards it. For Hayek, by contrast, the planner was guilty of an epistemological arrogance, of assuming that 'objective' knowledge of social processes could override the knowledge and interpretations that were available to those who conducted those processes (Hayek, 1942, 1945). The planning elite purports to look upon society as a whole, from a position of exteriority. Contra the intellectual snobbery of Mills, Hayek's complaint was precisely that intellectuals possess too much power in circulating ideas which when coupled to the state are used to illiberal ends. The power elite, from a neoliberal perspective, is a Rousseauian congregation of idealists and social scientists who believe they know what is in the interests of all, and then set about establishing plans through which to pursue this. Positivist faith in the methodologies of social science (including economics) produced a type of knowledge-power formation which was dangerously abstract, aggregative and uniform.

The epistemological ingredients of a neoliberal alternative to elite jurisdictions are twofold. Firstly, Hayek demanded greater respect for the knowledge which is at work in local, practical activity, much of which cannot be articulated or converted into theoretical prescriptions or rules. Someone working with physical equipment can know how to use it, know how it works, without being able to articulate why or provide an 'objective' view of the process (Hayek, 1945). The 'unconscious' nature of successful economic decision-making is crucial to the neoliberal critique of socialism, but it is equally leveled against neo-classical economists who believe that their calculations can be used to improve economic decision-making. Chicago School economists, including Knight, Friedman and Becker, all stressed the fact that 
economics was of little use in determining the most important decisions within the economy. Becker, who extended neo-classical analysis to various 'non-economic' domains, claimed to be studying something of which individuals were not themselves 'conscious':

The economic approach does not assume that decision units are necessarily conscious of their efforts to maximise or can verbalise or otherwise describe in an informative way reasons for the systematic patterns in their behaviour. (Becker, 1986: 7)

While the Chicago School were practitioners of the type of positivist social science of which Hayek was scornful, they were also conscious of the discrepancy between the economistic view of society and how economic agents actually experienced their activities in everyday life. In Friedman's analogy, the difference was like that between a billiard player who is expert at using angles and a geometrician who is expert at predicting the passage of balls (Friedman, 1953). Economists (or geometricians) are not there to improve on the embodied, instinctive knowledge of businessmen or entrepreneurs (or billiard players), or decide how they should act. In that sense, even in its positivist manifestation, neoliberal economics is not a jurisdictional science, and lacks any specific domain of authority. If neoliberal economists still constitute an 'elite', it is certainly not the same as the 'intellectual', which Hayek feared serve as "the sieve through which all new conceptions must pass before then can reach the masses" (1949: 374). The nature of elite decision-making is altered.

With individual entrepreneurs and consumers privately employing tools and embodied knowledge in an unconscious way, there must then be a second epistemological ingredient of neoliberalism. Transmission mechanisms are needed to relay information between these various distributed actors. The virtue of the market is that it can do this in real-time and it can do so without any conscious goal. Hayek argues that:

It is more than a metaphor to describe the price system as a kind of machinery for registering change, or a system of telecommunications which enables individual producers to watch merely the movement of a few pointers, as an engineer might the hands of a few dials.

(Hayek, 1945: 527) 
In place of a political agent, expert or intellectual taking decisions which impact upon the public in general, the price system acts as a cybernetic feedback system, such that private economic actors can constantly adjust their activities in relation to each other. In short, Hayek proposes replacing planners (including statisticians, intellectuals, social scientists) with a computational machine. In place of deliberate, conscious human jurisdiction being exercised over the public, there is the unconscious jurisdiction of 'machinery'. Before post-structuralists sought to 'cut off the sovereign's head', the neoliberal critique of elites had proposed replacing the alleged Platonists and experts who made up the socialist intelligentsia with a posthuman system for feed-back and spontaneous coordination, namely the market.

The idealized neoliberal subject is therefore sandwiched between two forms of technology, neither of which is perceived objectively or 'consciously'. Firstly, there are the tools of economic activity themselves: varieties of physical, financial and human capital to be exploited by enterprise. The successful businessman or entrepreneur is most likely unable to explain why certain actions were adopted, or why they were successful, but take decisions unconsciously according to instinct and immanent circumstances. Secondly, there is the 'machinery' of the price system, providing constantly changing information. Hayek argues that to stop and reflect on the price system or question why it works might be to break it. Again, our unconscious engagement with this technology is crucial to its effectiveness as a basis for collective coordination (Hayek, 1945: 527).

In this way, neoliberal critique targets all forms of Cartesian a priori, be that in the form of moral philosophy, social theory, methodology, formal notions of agency, replacing them with an embodied, contingent being who is oriented primarily towards various non-human forms of equipment, which include the price mechanism. The ideal neoliberal agent is a type of cyborg who is able to mediate constantly between the capital at its fingertips and the quantitative data relayed by the market, without stopping to reflect consciously on what it is doing. This 'dividual' is not taking deliberate decisions or making conscious judgments, but simply acting and reacting (Pickering, 2010; Halpern, 2014). It lacks a formal jurisdiction (of knowledge or power), beyond what it happens to be endowed with.

A core paradox of neoliberalism is that the construction of this type of self-organising, cybernetic system would be the work of intellectuals and states. That is, an anti-elitist project would require a vanguard of elites in order to advance it, initially via think 
tanks and intellectual networks, and then via sovereign states and multilateral bodies (Mirowski \& Plehwe, 2009; Mirowski, 2013; Davies, 2014). It is no coincidence that neoliberal reform has depended heavily on bodies with ambiguous or weakly defined jurisdictions, such as think tanks or international agencies, seeing as these offer avenues for elite power which are not mediated by existing liberal political formations. Via think tanks or the 'cultural circuit of capital' (such as business schools) neoliberalism is able to sustain a type of flexible, post-jurisdictional elite, which is waged against the jurisdictional elites of state bureaucracy, academic disciplines and professions (Medvetz, 2012; Thrift, 2005). And while the neoliberal project has necessarily been mediated via jurisdictional state agencies and professions - especially regulators and lawyers - its advance witnessed a deliberate, progressive weakening of the juridical, a priori logic of these agencies and experts, and its replacement with new technologies of calculation (Davies, 2010). In that respect, the genealogy of neoliberalism is characterised by a progressive weakening of its 'liberal' dimension (Burgin, 2012).

\section{Elites reinvented}

The condition of neoliberal society is one of pronounced inequalities of money and power, but with little jurisdictional logic to sanction the types of monopolies that result. Categories of 'public' and 'private', 'state' and 'market', do not adequately delineate domains of elite power under neoliberalism. Traditional professions (such as doctor, teacher, lawyer) retain their epistemological jurisdictions, but are no longer amongst the beneficiaries of capitalist expansion (Dorling, 2014). This has considerable sociological significance, seeing as professions have long been viewed (either critically or enthusiastically) as one of the crucial anchors between capitalism and the liberal public sphere, or financial capital and cultural capital (Bourdieu, 1984; Perkin, 2003; Marquand, 2004). The exercise of disinterested judgement by providers of knowledge-based services enables market society to co-exist with norms of inclusivity and disinterestedness. Professional discourses of normalisation are equally integral to Foucauldian regimes of disciplinary power (Foucault, 1991).

But as finance has broken away from the constraints of national regulation and democracy, the key agents in facilitating and profiting from this have been advisors and consultants (especially in Big Four accounting firms) who work constantly between institutions (including the state), earning fees at each point (Erturk et al, 
2007). 'Intermediaries' of this sort may play an even greater role in the acceleration of inequality than CEOs (Savage \& Williams, 2008). What Amoore has termed the 'consultocracy' offers another case of a neoliberal elite which strategically avoids any jurisdictional monopoly, never settling on any publicly visible mode of professional, normative or productive identity (Amoore, 2013). The consultocracy hovers in an exceptional domain between public and private, while the formation of seemingly oxymoronic 'Limited Liability Partnerships' is a symptom of the refusal of any a priori public form. The expansion of a sphere of governance lying between state and market, namely public service outsourcing, is a further example of how the logic of neoliberalism shifts power away from formal jurisdictions, and into the ambiguous spaces which lie between or across them (Froud, et al, 2014). This ceaseless 'skimming' of value and 'surfing' between institutions is characteristic of what Deleuze termed 'societies of control' (Deleuze, 1992).

Corporate governance experts have their own conceptual tool with which to analyse these processes, borrowed from game theory: 'agency problems'. Welfare economics adds another: 'information asymmetries'. Both of these assume methodologically that intermediaries (such as accountants or managers or creditraters) will constantly be on the verge of reneging on their responsibilities towards their clients or 'principles', simply because they can. This problem of 'temptation' (as Savage and Williams characterize it) is therefore written in to the very forms of knowledge that are often performatively constitutive of financial institutions. From an orthodox perspective, the problem can be solved either through manipulating incentives or redistributing information. But, save for the injection of some behavioural economics in the post-2008 climate, it is assumed that decisions are taken in a primarily egoistic fashion, measured in terms of remuneration. This debars the possibility of normatively binding collaboration, for better or worse.

The rise of shareholder value as the central goal of corporate governance (including of banks) in the 1980s is most emblematic of this new strategic template of intermediary activity (Lazonick \& O'Sullivan, 2000). Echoing neoliberals such as Hayek and Friedman, this philosophy assumes that decision-making will be more socially beneficial if it is oriented towards private financial maximization, than if it aims at some social good. This is a deflation of the public status of senior managers, but at the same time a basis for vast increases in remuneration. It is this deflation of public status that accounts for the changing role of intermediaries elsewhere: services which were once delivered on a professional basis, with distinctive symbolic 
and cultural value, become reduced to the status of market goods to be sold for a fee. Once they are regulated as ordinary businesses (with money an ordinary commodity), banks lose their extraordinary public status, and gain extraordinary profitability instead. The constant threat that the service-provider may renege on their promise to the purchaser means that they have an in-built justification for fee inflation, as a condition of trust-worthy behavior. As professional service firms and banks shifted to the status of 'just' businesses like any other over the 1980s and '90s (due to flotations, lobbied-for deregulations and de-mutualisations), elites became more intermediary and less juridical in nature.

Just as the neoliberal critique of elites was mobilized via institutions with ambiguous or fluid jurisdictions, so the new elites which arise under neoliberalism do not fit tidily into hierarchical institutions, with legitimate monopolies over formally defined spheres of power. Nor do they form an 'overlapping clique' of the sort attacked by Mills. They are possessed of 'capillary power', operating in a decentralised fashion, though that power is not disciplinary in a normative sense. What more can we say about them? Given the neoliberal critique of traditional, jurisidictional elites, how might we conceive of the neoliberal elite differently?

I suggest that, on the basis of a hermeneutics of neoliberal critique, we can identify two types of elite which are at work under conditions of advanced, financialised neoliberalism. The premise for both of these elite forms is that the 'ultimate' judgments or collective decisions will not be taken by 'conscious' human actors at all, but by the cybernetic, unconscious, non-human force of market machinery and other real-time feedback technologies. Hence, any type of elite power that is consistent with neoliberalism will not be one predicated on claims to 'ultimate' public or scientific authority of the elite themselves. Rather, elites come to occupy positions as translators of quantitative data. The price system is not the only machinery that can possess such authority. Recent paeans to Big Data have included the suggestion that managers of 'data-driven organisations' should hold no expertise of their own, other than knowing how to ask the right questions of data (McAfee \& Brynjolfsson, 2012). With the rise of 'smart cities', 'wearable tech' and the 'internet of things', previously unimaginable quantities of data can be collected by default to be mined at a later time. These offer the historically unprecedented "possibility of experiencing something not immediately available to consciousness" (Hansen, 2015: 139). 
The first elite form is one where the agent exists to mediate between two non-human semiotic systems. These might be termed 'cyborg intermediaries'. In the case of financial elites, these semiotic systems are vastly complex assemblages of prices, computer screens, cables, software, terminals and so on. In contrast to the professional banker, whose cultural and social capital needed constant tending as a form of discursive exclusion (Augar, 2008), the neoliberal financial elite excludes by virtue of semiotic complexity, little of which is mediated by humans at all (Haldane, et al, 2012). Just as the Hayekian entrepreneur is sandwiched between two forms of technology - capital to be exploited and prices to communicate information - the new financial elite responds to technological cues without conscious reflection or discursive deliberation. This is a domain of power that lies beyond the purview of most public institutions or even the executives which are ostensibly accountable for it. The acts of translation which are performed by 'cyborg intermediaries' are from one esoteric code into another, rather than from code into narrative. It is quite apt that much of the sociology of this terrain has been within the tradition of Science and Technology Studies (e.g. Lepinay, 2011).

Elites of this nature may be very highly remunerated, but they possess no real autonomy, power or authority in the liberal or Weberian sense of those terms. Not unlike the consumer, who receives cues from advertising or 'nudges' from policy, then displays a behaviour change as a result, the majority of financial elites are receivers and processors of information. They are not endowed with liberal subjectivity, but rather are victims of what Lazzarato terms 'machinic enslavement', in which non-discursive, 'asignifying semiotics' govern and enact decisions (Lazzarato, 2014). In contrast to processes of 'subjection', which produce certain types of human self-consciousness and reflexive understanding (such as discourses of 'entrepreneurship' or 'choice'), 'machinic enslavement' renders the person a "gear, a cog, a component part in the "business" and "financial" assemblage" (2014: 25). The machinery of contemporary capitalism mobilizes "partial and modular subjectivities, non-reflexive consciousnesses and modes of enunciation that do not originate in the individuated subject" (2014: 89). This is precisely the type of non-Cartesian, 'unconscious' agency that Hayek viewed as the driver of spontaneous organisation.

Beyond the neo-classical assumptions of 'human capital' or 'rational choice', Lazzarato suggests that financial traders have no humanity that is distinguishable from the machines that govern them: 
Instead of a rational subject who controls information and his choices, homo economicus is a mere terminal of asignifying, symbolic, and signifying semiotics and of non-linguistic constituents which for the most part escape his awareness. We are not only well beyond the individualism and rationality of homo economicus, we have moved beyond "cognitive capitalism". (Lazzarato, 2014: 100).

Central to Lazzarato's argument is the notion that non-discursive languages of machines are not representations of reality, but "simulate and pre-produce a reality that does not yet exist, a reality that is only virtually present" (2014: 86). This is another way of saying that machinic semiotics is 'performative', just as the social studies of finance has shown with respect to economics in certain circumstances (MacKenzie, 2006; MacKenzie et al, 2007). We should also note that price itself is a performative or non-representational type of sign, in the sense that it only exists by virtue of its representation (and chains of representation). A price that was not communicated would not be the price.

Traders surrounded by screens of price data are not, therefore, subjects viewing signifiers of some absent reality, but agents within a reality of telecommunications and information processors. "The sign flows circulating from computer to computer in real time constitute a reality that is as objective as material flows" (Lazzarato, 2014: 96). Decisions are taken along the way, but they are not taken at some 'objective' distance on the basis of conscious reflection or deliberation. They are effects of the system, which now includes the behaviors, bodies, brains of those employed by it. These cyborg intermediaries are defined in terms of their capacity to sense what is going on in real-time, not to perceive it at a distance (Hansen, 2015). Neuroeconomics, aimed at understanding the biological substrates of choice, is predicated on the assumption that choice is no longer a property of an autonomous subject any longer, but of somatic sensors and transmitters (Dow Schull \& Zaloom, 2011). Neural supplements aimed at traders, such as TruBrain, are an obvious step for 'cyborg intermediaries' whose powers of 'choice' are critical to the functioning of the whole machine. The rise of automated, high-frequency trading suggests that the need for human cyborgs within the financial system is not guaranteed in the long term (Ford, 2015; Lewis, 2015).

The second elite form is also one which privileges powers of translation, but here it is between the cybernetic, financial, market system and the liberal polity which that 
system now dominates. The neoliberal critique of jurisdictional elites, which seeks to elevate machinic systems to the status of ultimate authorities, does not necessarily seek to eliminate spheres of discursive deliberation, politics, public judgement, professional authority, regulation and liberal normativity, it merely seeks to usurp and constrain them. There is therefore a need for 'diplomatic intermediaries', capable of straddling both worlds, although the relationship between the two is highly asymmetrical. While charismatic central bank governors have the capacity (utilized or not) to speak politically against the financial system, the financial system has a far greater power to mobilize against politics. Successful CEOs of 'financialised' firms are those which can offer narratives about strategy that confirm the primacy of finance (Froud et al, 2006). In Lazzarato's terms, these elites are skilled in moving between spheres of 'signifiying semiotics' (explanations, justifications, proposals etc) and 'asignifying semiotics' (codes, data, processes etc).

Where 'diplomatic intermediaries' are arguably most crucial is in translating the mood of 'the markets' to political agents and states. Both the power and the opacity of the neoliberal system derive from the fact that numbers alone do not communicate their own meaning. As Streeck argues with respect to austerity measures,

From the viewpoint of 'the markets', a structurally sound budget is one that has sufficient reserves and institutional flexibility... The precise point at which this is attained remains open; much as 'the markets' want clarity from governments, they are not prepared to give it themselves.

(Streeck, 2014: 112-113)

The quantitative data of statistics, market prices, bond yields, Big Data, returns on capital do not signify anything, until their significance is provided by practices of interpretation. The liberal public sphere therefore plays an indispensable role in providing human narratives about non-human mechanisms. To use Hansen's distinction, sensations are converted into perceptions (2015). For example, during the depths of the Euro crisis in 2012, the media regularly featured employees of investment banks declaring that the Euro could not survive - not a judgement of the particular banker, but their interpretation of the judgement of the bond markets. A more famous example was the well-known case in which Alan Greenspan informed the newly appointed President Clinton that if he pursued any of his new spending plans, Greenspan would have no choice but to raise interest rates to prevent a weakening of the dollar, risking a recession (Reich, 2013). These 'diplomatic 
intermediaries' are not claiming jurisdictional authority within the public sphere, but merely acting as rapporteurs of what they understand is going on in the unconscious world occupied by millions of 'cyborg intermediaries'.

This asymmetrical relationship creates a lucrative opportunity to traditional elites located within the liberal public sphere (professions, media outlets, universities etc) to reconfigure themselves as 'diplomatic intermediaries', whose job it is to interpret and communicate the meanings of finance (and associated machinery) for the benefit of public audiences. Rather than enact a judgement in a jurisdictional sense, an interpretation of the facts is provided instead. Hence, accountants, auditors and credit-raters are reconfigured as delegates providing a public account of what is going on beyond the understanding of the public. Universities, consultants and the 'cultural circuit of capital' develop languages and narratives about what is taking place, beyond the realms of public discourse, just as the early protagonists of neoliberal thought produced narratives of 'enterprise' and 'competitiveness' as a cultural, normative accompaniment to a system that circumvents narrative altogether. While such narratives command public acceptance, the rewards available to those within the financial system (the 'cyborg intermediaries') can be justified on 'meritocratic' grounds to those outside of the system (Lazzarato, 2014: 100).

The relationship between finance and states may be the pre-eminent case of this diplomatic elite power. But there are other cases in which 'diplomatic intermediaries' occupy a critical role in translating the meaning of unconscious cybernetic systems. The business and policy applications of behavioral sciences and neurosciences requires gurus capable of communicating what brains or bodies are 'doing', 'wanting', 'feeling', in ways that does not involve the voice of the subject(s) under observation. Cartesian language is super-imposed upon otherwise anti-Cartesian, cybernetic accounts of agency (producing manifold philosophical contradictions in the process) (Bennett \& Hacker, 2003). The rise of Big Data privileges those capable of mediating between mathematical analytics and empirical narratives about what is being represented (Andrejevic, 2013). Numbers, bodies, brain activity and behaviors are not self-narrating, and their significance can never just emerge of its own accord. In these cases, the asymmetric relationship is reversed, and the unconscious, distributed system is represented in ways in which it can be controlled by marketers, managers, 'nudges', security services and so on. 


\section{Conclusion: new crises of elites?}

What Savage and Williams term the "capillary power" of finance helps us to understand why contemporary elites seem to evade public judgement and lack visible public jurisdictions. This new distribution and ontology of power undoubtedly marks a shift away from the Millsian definition of elites, as those who took conscious decisions, with national consequences, often in alliance with each other. This article has sought to add some further nuance, both to that notion of capillary power and to how new elites are conceived as a result. In particular, it is important to recognise the extent to which neoliberal thought is also a critique of elites in the Millsian sense, undermining modes of jurisdictional authority over designated domains of power and value, and instating new types of information circuits and intermediary power, which potentially bi-pass or subvert the liberal public sphere. The Hayekian critique of 'conscious' planning opens up space for new types of elite, who are either unreflexive regarding their power, or adopt the role of powerful interpreters mediating between the 'unconscious', cybernetic world of finance and that of politics. Both of these are possessed of powers of translation, rather than of public decision. I've termed these elites 'cyborg intermediaries' and 'diplomat intermediaries' respectively, using Lazzarato's distinction between subjective, signifying semiotics and machinic, asignifying semiotics, to theorise these different types of elite power.

The inability to exert judgement over finance - an inability which finds expression in the demand for bankers' prison sentences, oaths to be sworn, a seizing of their assets and so on - is a function of the exceptional status accorded to finance within the neoliberal system. The technology of financial markets comes to occupy the place traditionally held by elites, of the Millsian variety, hence there are no deliberate, coordinated, 'big' decisions being taken over the public, legitimately or otherwise. Neoliberal elites, to the extent that they engage in public discourse, expend considerable efforts explaining why there is no alternative to the rule of finance, as manifest in austerity policies.

Yet this system is clearly not immune to forms of legitimation crisis. As the public narratives of 'competitiveness' and 'meritocracy' lose plausibility (as they have done since 2008), questions turn to what really goes on inside the secret, machinic languages of the financial system. Concerns about inequality have now penetrated the very bodies that were once credited with spreading neoliberal ideas, such as the World Economic Forum and the IMF. Yet aside from such public breakdowns of 
hegemony in a traditional sense (and whose impact upon the cybernetic system of finance is not guaranteed), the analysis presented here also provides a theorisation of new types of crisis that will strike under advanced, financialised neoliberalism. 'Post-hegemonic systems' of domination are still victims of legitimacy crises, although these do not necessarily weaken them, given they are not dependent on Gramscian or Weberian norms of legitimation in the first place.

The archetypal financial agent, as characterized by Lazzarato, does not exercise conscious, reflexive subjectivity, but operates amidst computer programmes and market systems which render the trader a type of cyborg, processing information, according to routines and scripts produced by machines. But when such an agent suddenly discovers their subjectivity, reflects on their situation, consciously decides to act, then the outcome is unpredictable and political. Most likely it will be some act of fraud or corruption - a giving way to temptation - such as those that came to symbolise the rotten state of finance post-2008. And yet the difference between 'scandals' and ordinary financial activity lies partly in protagonists being caught, and partly in 'deliberate' nature of a plot. Finance also normalises practices of representational distortion, such as the elimination of 'profit' for purposes of tax avoidance, but in a way that is in keeping with the systemic format (Sikka \& Willmott, 2013). Normal acts of profitable re-signification, as conducted by the Big Four, are not classed as 'scandalous'.

The flipside of this sudden eruption of subjectivity amidst a world of 'asignifying semiotics' is the phenomenon of whistle-blowing, whereby elites in the position of 'cyborg intermediaries' (processing information, not exercising conscious subjectivity) dramatically take it upon themselves to enter the public sphere as 'diplomat intermediaries' or to facilitate leaks. Industries and agencies which process large amounts of data are vulnerable to this ethical reorientation or 'hacker ethic', of which Edward Snowden is perhaps the most prominent case. The possible ends to which the hacker, fraudster or whistle-blower puts this power are limitless. As organisations, cities and private lives become increasingly 'data-driven', but still dependent on some form of human agency, new opportunities for conscious manipulations and disruptions will arise. Scandals surrounding the app-based taxi network Uber (such as awarding senior managers the 'God View' which tracks the movements of individual account holders without their knowledge) give a sense of how the boundary between 'unconscious' and 'conscious' forms of cognition is penetrated as form of power. 
Attention needs to be paid to both the machinery and the discourses of elite power. Mills defined the project of elite studies as follows:

For every epoch and for every social structure, we must work out an answer to the question of the power of the elite. The ends of men are often merely hopes, but means are facts within some men's control. That is why all means of power tend to become ends to an elite that is in command of them. And that is why we may define the power elite in terms of the means of power - as those who occupy the command posts.

(Mills, 1999: 23)

The hacker or the whistle-blower may not resemble elites of the sociological variety studied by Mills. But neoliberalism, and digital financialisation, force us to reconsider both the "means" within some men's control, and also the particular location of the command posts. What Lazzarato terms 'machinic enslavement' means that, even those who have the means of power at their finger-tips, this rarely translates into a reflexive self-consciousness of being in 'command', save for when they unaccountably decide to seize this potential. Meanwhile, there are various intermediaries - former professionals, ex-intellectuals, one-time journalistic institutions - willing to work as the interpreters of what the financial machine is saying from one moment to the next, as a condition of attaining economic security. Yet the political instability of the system resides in the fact that the means of power are so complex, so distributed, that possibilities for the exercise of a public decision could be taken at any point in a chain. 


\section{REFERENCES}

Abbott, A. D. (1988). The System of Professions: An Essay on the Division of Expert Labor. Chicago: University of Chicago Press.

Amoore, L. (2013). The Politics of Possibility: Risk and Security Beyond Probability.

Duke University Press.

Andrejevic, M. (2013). InfoGlut: How Too Much Information Is Changing the Way We Think and Know. Routledge.

Augar, P. (2008). The Death of Gentlemanly Capitalism: The Rise And Fall of London's Investment Banks. Penguin UK.

Becker, G. S. (1976). The Economic Approach to Human Behavior. Chicago:

University of Chicago Press.

Bennett, M. \& Hacker, P. (2003). Philosophical Foundations of Neuroscience. London: Wiley.

Boltanski, L., \& Chiapello, E. (2007). The New Spirit of Capitalism. London: Verso.

Boltanski, L., \& Thévenot, L. (1999). The Sociology of Critical Capacity. European Journal of Social Theory, 2(3), $359-377$.

Bourdieu, P. (1984). Distinction: A Social Critique of the Judgement of Taste. Harvard University Press.

Burgin, A. (2012). The Great Persuasion: reinventing free markets since the Depression. Harvard University Press.

Castells, M. (1996). The Rise of the Network Society. Cambridge, Mass: Blackwell Publishers.

Cohan, W. (2015). 'How Wall Street's bankers stayed out of jail', The Atlantic, September 2015

Dahl, R. (1982). Dilemmas of Pluralist Democracy: Autonomy Vs. Control. Yale University Press.

Dahl, R. A. (1958). A Critique of the Ruling Elite Model. The American Political Science Review, 52(2), 463-469. doi:10.2307/1952327

Dahl, R. A. (2005). Who Governs?: Democracy and Power in an American City. Yale University Press.

Davies, W. (2010). Economics and the 'nonsense' of law: the case of the Chicago antitrust revolution. Economy and Society, 39(1), 64.

Davies, W. (2013). When is a market not a market? 'Exemption', 'externality' and 'exception' in the case of European State Aid rules. Theory Culture \& Society, 30: 2, $32-59$ 
Davies, W. (2014). The Limits of Neoliberalism: Authority, Sovereignty and the Logic of Competition. SAGE.

Davies, W. (2016). Moral Hazard: The shifting ethos of neoliberalism. New Left Review. 99, May-June

Deleuze, G. (1992). Postscript on the societies of control. October, 59, 3-7.

Dorling, D. (2014). Inequality and the 1\%. London: Verso Books.

Dow Schull, N. \& Zaloom, C. (2011). The shortsighted brain: Neuroeconomics and the governance of choice in time. Social Studies of Science. 41: 1. 515-538

Erturk, I., Froud, J., Johal, S., Leaver, A., \& Williams, K. (2007). Against agency: a positional critique. Economy and Society, 36(1), 51-77.

Ford, M. (2015). Rise of the Robots: Technology and the Threat of a Jobless Future. New York: Basic Books

Foucault, M. (1991). Discipline and Punish: The Birth of the Prison (New Ed).

Penguin.

Frank, T. (2010). One Market Under God: Extreme Capitalism, Market Populism and the End of Economic Democracy. Random House.

Friedman, M. (1953). Essays in Positive Economics. University of Chicago Press: Chicago.

Froud, J. (2006) Financialization and Strategy: Narrative and Numbers. London:

Routledge.

Froud, J., Johal, S., \& Moran, M. (2014). Outsourcing services, co-dependence and elite power. Retrieved 15 December 2014, from

http://www.discoversociety.org/2014/12/01/outsourcing-services-co-dependenceand-elite-power/ Haldane, A. (2011). Control rights (and wrongs). Bank of England. Haldane, A. et al (2012) Towards a Common Financial Language. Bank of England Halpern, O. (2014). Cybernetic Rationality. Distinktion: Scandinavian Journal of Social Theory. 15: 2. 223-238

Hansen, M. (2015). Feed-Forward: On The Future Of Twenty-First-Century Media. University of Chicago Press

Harrington, B. (2015). 'Inside the Secretive World of Tax-Avoidance Experts', The Atlantic, October $26^{\text {th }} 2015$

Harvey, D. (2005). A Brief History of Neoliberalism. Oxford: Oxford University Press. Hayek, F. A. (1949). The intellectuals and socialism. The University of Chicago Law Review, 417-433.

Hayek, F. A. (1945). The Use of Knowledge in Society, The. NYUJL \& Liberty, 1, 5. 
Hayek, F. A. v. (1942). Scientism and the Study of Society. Part I. Economica, 9(35), 267-291.

Hayek, F. A. von. (1944). The Road to Serfdom. G. Routledge \& Sons: London. Lash, S. (2007). Power after Hegemony: Cultural Studies in Mutation? Theory, Culture \& Society, 24(3), 55-78.

Kahn, R. (2012). The Sociology of Elites. Annual Review of Sociology. 38: 1. 361377

Lazonick, W. \& O'Sullivan, M. (2000). Maximizing shareholder value: a new ideology for corporate governance. Economy \& Society, 29: 1, 13-35

Lazzarato, M. (2014). Signs and Machines: Capitalism and the Production of Subjectivity. Semiotext(e).

Lewis, M. (2011). The Big Short: Inside the Doomsday Machine. London: Penguin. Lewis, M. (2015) Flashboys: A Wall Street Revolt. London: Penguin.

MacKenzie, D. A. (2006). An Engine, Not a Camera: How Financial Models Shape Markets. Cambridge, Mass: MIT.

MacKenzie, D. A. et al (eds) (2007) Do Economists Make Markets?: On the Performativity of Economics. Princeton, N.J: Princeton University Press.

Marquand, D. (2004). Decline of the Public: The Hollowing Out of Citizenship. Wiley. McAfee, A., \& Brynjolfsson, E. (2012). Big Data: The management revolution. Harvard Business Review, October.

Medvetz, T. (2012). Think Tanks in America. Chicago: University of Chicago Press. Mills, C. W. (1999). The Power Elite. Oxford University Press.

Mirowski, P. (2013). Never Let a Serious Crisis Go to Waste: How Neoliberalism Survived the Financial Meltdown. Verso Books.

Mirowski, P. \& Plehwe, D. (eds). (2009). The Road from Mont Pèlerin: The Making of the Neoliberal Thought Collective. Cambridge, Mass: Harvard University Press.

Mises, L. (1990). Economic Calculation in the Socialist Commonwealth. Ludwig von Mises Institute.

Mises, L. V. (2009). Socialism: An Economic and Sociological Analysis. Ludwig von Mises Institute.

Mizruchi, M. S. (2013). The Fracturing of the American Corporate Elite. Harvard University Press.

Nader, L. (1972). 'Up the Anthropologist: Perspectives Gained from Studying Up'. In In: Dell H. Hymes (Ed.) Reinventing Anthropology. New York, Pantheon Books, 1972. p. 284-311.

Perkin, P. H., (2003). The Rise of Professional Society: England Since 1880. Routledge. 
Pickering, A. (2010). The Cybernetic Brain: Sketches of Another Future. University of Chicago Press.

Piketty, T. (2014). Capital in the Twenty-First Century. Harvard University Press.

Reich, R. B. (2010). The Work of Nations: Preparing Ourselves for 21st Century

Capitalism. Knopf Doubleday Publishing Group.

Reich, R. B. (2013). Locked in the Cabinet. Knopf Doubleday Publishing Group.

Rose, N., \& Miller, P. (2010). Political power beyond the State: problematics of government. British Journal of Sociology, 61(s1), 271-303.

Sassen, S. (1991). The Global City: New York, London, Tokyo. Princeton, N.J:

Princeton University Press.

Savage, M. (2014a). FOCUS: Social change in the 21st century: the new sociology of 'wealth elites'. Retrieved 15 December 2014, from

http://www.discoversociety.org/2014/12/01/focus-social-change-in-the-21st-centurythe-new-sociology-of-wealth-elites/

Savage, M. (2014b). Piketty's challenge for sociology. The British Journal of Sociology, 65(4), 591-606.

Savage, M., \& Williams, K. (2008). Remembering elites. Blackwell Pub.

Schumpeter, J. A. (1976). Capitalism, Socialism and Democracy (5th ed). London:

Allen and Unwin.

Sikka, P. \& Willmott, H. (2013). The Tax Avoidance Industry: Accountancy Firms on the Make. Critical Perspectives on International Business. 9: 4. 415-443

Spross, J. (2015). 'Too big to punish: why Wall Street gets away with piddling fines', The Week, $28^{\text {th }}$ May 2015

Streeck, W. (2014). Buying Time: The Delayed Crisis of Democratic Capitalism. Verso Books.

Thrift, N. J. (2005). Knowing Capitalism. London: SAGE Publications.

Walzer, M. (1983). Spheres of Justice: A Defence of Pluralism and Equality. Oxford: Robertson.

Weber, M. (Oxford). Politics as a Vocation. In From Max Weber: Essays in Sociology. 1991: Abingdon. 